\title{
HIGH SCHOOL TO UNIVERSITY: WHAT SKILLS DO STUDENTS NEED?
}

\author{
Eileen Daniel \\ Frost Library, Glendon College, \\ York University \\ 2275 Bayview Avenue, Toronto, ON M4N 3M6 Canada \\ E-mail: edaniel@yorku.ca
}

\section{ABSTRACT}

The problem of transferring library and information searching skills from high school to college is not new, but has become intensified in the last decade by the pressures of the information explosion, new technologies and budget reductions. While skills objectives for both high school and first year university are similar, the context and emphasis for the use of these skills differs in several respects. The survival skills students acquire in high school, particularly in the areas of periodical index use and computer search strategies, need to be expanded. Increased communication between high school teacher-librarians and academic librarians is recommended.

A constant complaint of university and college librarians for many years has been that first year students lack the skills to be able to use the university library and its resources successfully. Goodin (1991) includes quotes from 1981 and 1983 that "students...are, almost without exception, totally innocent of how a library works and do not have even a vague idea how to set about finding information they need or want when they arrive at a college or university." In 1985 Matheson notes the lack of basic skills needed to find information in the university library. In 1989 Krentz and Gerlach's report for the University of Wisconsin begins with another quote "Don't high school librarians teach library skills to students any more?" and McNeer (1991) states "Year after year, students arrive on our campuses unable to use our libraries." (p. 294) Other librarians (Adams, 1988; George, 1988; Altan, 1989; Knudsen \& Orpinela, 1992) have treated the same theme from a different angle by offering their lists of the skills needed by first year students to use the academic libraries successfully. In the current library environment the problem has become even more pressing.

In the past decade, major waves of change have swept over the library instruction scene along with the rest of the education world. Librarians are trying to cope simultaneously with the information explosion, and the technology revolution. The amount of published information doubled every eight years, even back in 1984, faster for scientific and technical information (Large, 1984, as cited in Eisenberg and Spitzer, p. 115). Tools to access this information, like indexes and encyclopedias, expand in similar fashion. Moreover, sources of information formerly inaccessible have been flung open beyond the library by communications technology. The Internet offers vast quantities of material put out by any organization or individual that has a computer, a modem and access to a server. Librarians also have to learn to use the computer, video, sound, and other technology to deal with this information explosion. There are us new and different demands of costs, skills, esoteric terminology and a plethora of constantly changing systems.

Faced with these demands, educational aims have moved to promoting skills which will give students a strategy for coping with the overload of the new information age environment - those included in "information literacy," which can be defined briefly as knowing when one needs information, where to find information, how to evaluate information, and how to use information in decision making or problem solving. (Daragan \& Stevens, 1996) Publications by researchers such as Kuhlthau $(1988,1991)$ have directed attention to the process by which students formulate questions, search for information and use it to create answers. Inherent in this is the ability to think critically, and to make informed selections from among the array of choices offered. Students also have to learn the skills needed by the new technology, particularly those which enable them to access material in electronic format, and incorporate these into their own work (see, for example, Loomis \& Fink, 1993). At the same time the organization of materials in libraries still requires the old library skills. 
Learning to use the library was once a fairly simple activity for the user. Once the catalogue and library locations were comprehended, the user had a strong chance of becoming an independent and effective user. Library searching was relatively straightforward and the end-product was easily retrievable. Today this is just the start of the quest. The user is now faced with a vast array of search options, and a less definable set of retrievable outcomes...In addition the search engines used by the searchers are of many different designs and formats, placing even greater demands on the search inquirer. This is the context in which our library users now work. (Debowski, 1996, p. 144)

At the same time budget reductions force staff cutbacks even as needs grow. Few universities have mandatory or credit courses in library skills or staff dedicated to library instruction. Reference desk staff have little time to explain complexities to student after student who lacks the knowledge and skills required to negotiate the resources of the university library.

My frustration with this situation led me to hypothesize that one cause of this problem and also one possible solution might lie in the instruction in library skills students receive in high school. Encouraged by some teacher-librarians, similarly concerned about the future of their students, I undertook an investigation of the skills required of students in their final year of high school and those needed in the first year of university. My primary focus was on the Canadian province of Ontario, where students conduct independent research projects as part of their course work during their final high school year. I chose to investigate a broad spectrum of sources, covering not only a search of the literature, but also unpublished documents from schools and universities and postings and comments from Internet sources, particularly listservs of school and academic instruction librarians. I met with a discussion group of teacher-librarians and worked closely with four teacherlibrarians from a varied group of high schools from different school districts in the Toronto area. I also conducted interviews with three groups of first-year students at York University.

In this paper, "universities" is used for universities and colleges, "academic libraries/ans" for libraries/ans in universities and colleges, "school libraries" for high school libraries, "teacherlibrarians" for high school librarians, and "first year students" for students in their first year of a university or college.

\section{OBJECTIVES FOR INSTRUCTION}

To determine the extent to which teacher-librarians and academic librarians agreed on instructional objectives, I examined some 50 documents from school and academic libraries, mostly in North America. I had expected two different sets of objectives from these two environments, but found instead that the two lists were remarkably similar. These have been integrated as follows:

\section{Information Literacy Skills}

- know the steps involved in the research process from basic idea to final presentation;

- be able to formulate the search question and identify terms to use to search for information;

- know the different types of information sources available and where to go to find them;

- recognize the difference between fact and opinion, fiction and non-fiction, primary and secondary, Canadian and non-Canadian sources;

- employ critical thinking skills to evaluate information found for authority, bias, prejudice, stereotypes, relevance, timeliness;

- understand copyright, plagiarism and intellectual property;

- synthesize information found in relation to the topic, subject and audience;

- produce a well-constructed presentation;

- evaluate the product and process.

Library and Information-Handling Skills

- know the general layout, policies and procedures of library operation (circulation, reference, book stacks in call number order, etc.); 
- know the different types and formats of materials found in a library, e.g., books, periodicals, reference materials, AV materials, maps, government documents, and how each is useful;

- use the library catalogue to search by author, title, subject;

- know the different elements of a catalogue record and what each is useful for;

- understand that periodical articles are searched through a periodical index;

- understand the elements of a periodical index citation, and what each is useful for; be able to find the journal on the shelf ;

- know the parts of a book, e.g., index, table of contents, and their uses;

- be familiar with different types of reference materials, e.g., encyclopedias, dictionaries, almanacs, and their uses;

- understand classification schemes and use them to find materials on the shelf;

- identify and use bibliographies for searching; understand the use of abstracts and annotations in bibliographies; be able to compile bibliographies in correct bibliographic form;

- understand key library terminology.

\section{Computer Skills}

- be able to operate a computer (keyboard, mouse, drop-down menus, hypertext links, print, download etc.);

- understand the basics of keyword searching and be able to broaden or narrow search terms

- understand Boolean logic ("and" "or" operators);

- use electronic mail;

Do first year students have these skills?

Krentz and Gerlach (1989) and Coupe (1993) note the scarcity of good surveys on the library skills and knowledge of students entering college. In Coupe's survey of John Hopkins freshmen, $97.5 \%$ of students knew a catalogue may be searched by title, author and subject, but only $60 \%$ could use them correctly in the online catalogue. While $44 \%$ knew that "and, "or" and "not" are Boolean operators, only $28 \%$ used them correctly. $86 \%$ knew what a bibliography is, but only $31.6 \%$ knew the difference between citations to books and citations to journal articles. And only $15 \%$ knew not to search the catalogue for journal articles.

\section{Student Shortfalls as Identified by Academic Librarians}

Comments from academic librarians, listserv postings and published articles (see, for example, Altan; Kunkel, 1996) show general agreement on problem areas. At the top of the list are:

Finding and using periodical articles. Few students even know a periodical index must be used to search for a periodical article, much less know the skills to select and search a variety of print and electronic indexes, interpret an index citation to find the journal on the shelf, and determine the value of the article.

Understanding the principles of computer searching. Many students assume that all that is needed to find information is to type in a word or phrase on "the computer." Most are familiar with the OPAC (the online public access library catalogue), but they do not understand the variety of other systems and databases available; they lack strategies to construct or choose good keywords, or find alternate search terms; they are uncritical of the information they find; they assume that their computer search has retrieved all possible records and that if they haven't found what they are looking for with their search terms, there is nothing on their topic in the library.

Understanding how libraries are organized, the various types and formats of materials found in the university library (microform is a special problem) and how to select appropriate tools to locate information

- Defining the search topic

- Knowing who to ask for help

- Understanding controlled vocabulary (subject headings, descriptors) - what it is, 
how to identify it, when to use it to search, how it differs from keywords

- Distinguishing between citations to books, periodicals and book chapters

- Familiarity with library terminology (e.g., reserves and reference, holds and holdings)

- Understanding the principles of call numbers and classifications, and how Library

of Congress (LC) classification differs from Dewey Decimal System

- Realization of the time and steps needed to get good information on their topic.

High school teacher-librarians, reluctant to believe that their students are not equipped to cope with university research, postulate that the students without library skills and knowledge are those who did not have instruction in high school, and that the students presenting themselves with problems at the reference desk are those who do not know how to function on their own. It is undoubtedly true that academic librarians' perception is colored by dealing with students who lack any information-finding skills. In student groups at York University, $45 \%$ of students reported having had high school library instruction. These students reported less library anxiety and greater awareness of the reference desk as a source of help. (York student: "What I learned from high school is that you don't need to freak out because it's big-it's just a library.") However almost all reported the OPAC as their only information-finding strategy, very few knew of periodical indexes, and several did not seem to realize that Dewey call numbers were different from LC. Surveys of freshmen by Parenteau (1994) at Alverno College and Kester (1994) in North Carolina report similar or even more limited knowledge. It is also unlikely that the students who request help are the ones without skills. Other surveys (Altan, 1989; Valentine, 1993; University of Calgary, 1996 ) report that students who feel inadequate ask friends for help rather than approach the reference desk with a "dumb" question.

\section{Possible Causal Factors of the Skills Gap}

Why aren't the students better able to use university library resources? Because they find themselves in an unfamiliar environment with an enormously increased resource base that is far more complex, less helpful, and more demanding than they had ever anticipated.

The first year university experience is overwhelming for many students. Studies at the University of Guelph (Benjamin,1990) and the York University (1994) describe "the sheer magnitude of the discrepancy between high school and university as places to do academic work." (Benjamin, p. 26) In high schools, the environment is supportive, the teachers work closely with their students, provide assignments within the students' capability and watch out for those having trouble. The student may well find the university large, impersonal and uncaring. Workload and time pressures increase. Few faculty have pedagogical training. The assignments they give may be unsuited to the capacity of the students at this stage, and explain much of the students' difficulty in defining their topic (Leckie, 1996). Most faculty also assume that students possess the library research skills needed to do their assignment (Cannon, 1994). Other researchers (Kuhlthau, Turock, George \& Belvin, 1990; McNeer,1991) have suggested that students' cognitive development may not be advanced enough to cope. Reference librarians are thinly spread, and, like faculty, few of them have pedagogical training.

The university library forms part of this intimidating and unfamiliar experience. A repeated comment of the York students (see also Collins, Mellon \& Young, 1987, and others), was feeling overwhelmed by the size and scope of the operation of the academic library. In the university there are many service desks, often many libraries, each with a specialized function and different staff. Materials are arranged in separate sections which may be different from the arrangement they are accustomed to. There may be several banks of computer workstations. Usually it is fairly straightforward to find the OPAC, but where are the familiar CD ROM encyclopedias? Or the simple all-purpose CD-ROM periodical index? Here there are multiple bays of print encyclopedias, and large numbers of periodical indexes in print, CD-ROM and tape-mounted formats, all on different subjects, searchable in different ways and usually providing citations, not full text. Their unsophisticated keyword searches bring up hundreds of items or none at all. No one has structured the student's search to ensure success. Without a clear understanding of the process and its possible pitfalls, and an alternate set of strategies to try if the first does not work, the first year student is left helpless and frustrated. Anxiety and insecurity lead to the "cereal choice" and "hungry rats" 
syndromes described by Oberman (1991) and Keefer (1993). When confronted by too many choices the student ends up grabbing the nearest, and when desperation sets in the student forgets skills practiced in less stressful situations. The one thing they do expect is that in so large a library there must be some material on their topic.

As a result of the "information revolution," the focus of the teaching of information-seeking skills in schools has moved away from teaching primarily library and information-handling skills. For example library skills figure strongly in the 1982 Partners in Action document of the Ontario Ministry of Education and the 1983 document Information Skills...a Continuum from the school board of Northumberland-Newcastle. A decade later in the Ontario 1995 Information Literacy and Equitable Access document and the Northumberland-Clarington (same board as above) Five-year Plan for Computer-based Technologies 1994-1999 the focus has shifted to broad information literacy issues and access to information technology. Ambitious objectives are set for computer skills in schools (see, for example, Eisenberg \& Johnson, 1996). The widespread belief that all information is now available by computer fueled, by media reports, directs the funding priorities of politicians and administrators. Getting on the Internet is a major preoccupation and, indeed, the Internet does provide a gateway to a wealth of material otherwise unobtainable within the budget of the small school library. Electronic encyclopedias and simple periodical indexes now can be purchased at a cost little different from that of print materials and offer the prospect of easy keyword access with full-text printouts. The cost of maintaining print runs of periodicals is saved and frustration when the periodicals are not available in the library is eliminated.

The result of the information literacy imperative is to emphasize the problem solving process. The "Big Six" approach (Eisenberg \& Berkowitz ,1992) is being adopted by many schools and school boards as the standard process for their information literacy program. The Big Six defines the problem-solving process as six main steps: task definition; information seeking strategies; location and access; use of information; synthesis; and evaluation of the process. As a formulation of the steps of the research process, it is easily understandable and corresponds closely to those put forward by other researchers. (Eisenberg \& Brown, 1992) Much attention is now put on resources outside the library and on the presentation format, and much less on the skills required to locate and access the resources within the library.

In the university however, the focus is still the increasingly sophisticated skills needed to access the extensive and varied resources within the university library. The introduction of computers not has created a simplification of library searching but the need to integrate a new set of complex skills with the old, for print resource skills are still needed, particularly for historical material. Jakobovits and Nahl-Jakobovits (1987) make the point that a library's organization is determined by the characteristics and content of the material, rather than by the user, and King and Baker (1987) discuss how new technologies have added to this complexity. To find information successfully, the student must have learned to understand this organization and work within its framework. The most frequently-required presentation format will be the research essay. The Internet is not yet a major source of information for undergraduate courses because of its disorganization and lack of authority. "Spend a couple of hours on the Internet to save yourself a couple of minutes in the library" is a popular listserv signature file addition.

Teacher-librarians might object, quite rightly, that they have a much wider mandate than to prepare students for post-secondary education, and that information literacy skills will provide lifelong learning. Moreover, it is not that they have given up teaching their students library-related skills. All the schools that I visited assured me that the library and information-handling skills in the basic list were taught from the elementary school on; indeed, these were covered in the projects and assignments I have seen, but usually on a limited set of resources and in a structured setting. Library skills classes also usually specific to certain courses. With budget and staffing cutbacks, it would be possible for students to complete high school without having taken any library instruction at a senior level, yet think they have library skills. "We may be teaching just enough about using the library to make students think they don't need to know any more." (Farber, 1984, as cited in Wesley, p. 24)

We must also consider the learning characteristics of the students themselves. Collins, Mellon and Young (1987) and others have written about the need to consider diverse learning styles, cultural differences, and problems faced by recent immigrants and those with language difficulties. Every teacher knows only too well that learning does not necessarily follow teaching. A fascinating study is described by Moore (1995), in which researchers followed closely a group of 6th grade students as 
they carried out a library assignment. Their wide variation in skills application, task definition and ability to think flexibly still applies to students many years older.

Students are looking for the easiest and fastest way to complete their assignments (Valentine, 1993, p. 304). Why learn controlled vocabulary searching in school when the first keyword provides enough to get by? Why take a library skills workshop in first-year university if the professor does not require it for a mark? Students develop survival skills, which they use even when they know that better methods are available. They establish a library research routine for themselves and ask for help only when desperate. The University of Calgary survey indicated that the preferred, sometimes the only, method for students to find information in the library was to search the OPAC by keyword to find a call number of a work that looked relevant, then to go to the stacks and browse the shelf. This might account for the results shown in the studies of Coupe (1993) and others that the results of skills tests from seniors differed little from those of first year students. Since most computer searches will retrieve some hits, with no indication to the searcher how much information might have been retrieved with a better strategy, students feel they are competent searchers when actually they have a low level of computer searching skills. (York student: "I don't need library instruction. You just have to go to the computer and type in your search." Interviewer: "Which computer? Which database?" Student (impatiently): "Just the computer.")

\section{What Skills Needed for University?}

The skills students need are the skills teacher-librarians are already teaching them, if the objectives list given earlier is accurate. What they need in addition is to have a solid understanding of the principles behind the skills so they can apply them to a new, bigger, more complex environment. Key areas for understanding are:

- a basic research process strategy (yes, the "Big Six" is OK)

- the basic principles of organization of materials and services in any library

- the different types and formats of materials in a large library and how to access them

- the limitations as well as the advantages of computer searching and the principles of constructing good searching strategies

- the process of finding periodical articles in both print and electronic formats, from the selection of an index through the search process to the identification of the journal issue and finding it on the shelf. (Don't throw out your print indexes!)

- the elements of a catalogue record, an index citation and a bibliographic citation, whether for a book, journal article, book chapter or other material type

- the use of controlled vocabulary for searching, and how to find good terms

- Strategies for critically evaluating materials found according to various criteria

- Principles of classification and call number construction and how Dewey differs from

LC

- Terminology used in the academic library (e.g., "library lingo" on the BI-L listserv)

- Where to go for help for problems (e.g., reference desk, circulation desk, instructor)

- Alternate strategies to try if the first does not work, and how to look for clues for further information

\section{Toward a Smooth Transition}

One obvious answer to a better transition to university is better communication between schools and universities. Altan (1989) and Krenz \& Gerlach (1989) suggest the need to formulate joint standards and identify acceptable levels of skills and proficiencies at appropriate levels of development. In any area there will probably be conferences, committees, professional development days or other opportunities for librarians to meet. Arrange discussions with librarians from the other sector and invite them to your meetings. Ask to go to their meetings. Arrange visits to the other institution.

The teacher- librarian will need to give instruction for college-bound students a different emphasis from that of the rest of the high school population. They need to have practice in dealing with assignments that are not structured, and resources which are complex, especially print and electronic periodical indexes. One way of convincing high school students they need more than school library survival skills is to arrange to visit a local academic library to work on a project with them. In areas where university libraries are a key resource for high school students policies and 
procedures are usually worked out for use of the university library and provision of classes. Even in universities which discourage high school classes academic librarians may be receptive to providing a session to a group of teacher-librarians. Another increasingly available resource is virtual access to academic libraries via the Internet. Many libraries now have instruction pages on the Web in addition to catalogues and other information resources.

In some areas there are more formal links already set up to encourage cooperation (See, for example Jesudason, 1993, Nofsinger, 1989, Wollter, 1989). If a linkage program is set up for your school/university, you can ensure that libraries are included in it. Waterloo, Ontario is an example of a formally organized cooperative program among school, university and public libraries (Waterloo County, 1994).

Academic librarians also have a role to play in smoothing the transition for students, particularly in simplifying and clarifying academic library procedures. In most universities however, their ability to provide more than minimal instruction and continuing contact with students is limited, and budget reductions are curtailing this even further. The best opportunity may well be at the high school level, in smaller settings where teachers have closer contact with their students, even though it is often difficult for teacher-librarians to persuade principals and teachers to provide opportunities for students to learn these skills. But the effort will benefit the student at university and after. As one academic librarian expressed: "It's the individual teacher-librarians who make a difference."

\section{REFERENCES}

Adams, M. S. (1989). Bridging the gap: What do they need to know? Catholic Library World, 60 (5), 220-221.

Altan, S. (1989). Desperately seeking standards: Creating competent college-bound library users. In T. B. Mensching (Ed.), Reaching and teaching diverse library groups.( Papers presented at the 16th National LOEX Library Instruction Conference, Bowling Green State University, 5th \& 6th May 1988). (pp 19-24). Ann Arbor, MI: Pierian Press.

Altan, S. (1988). Survey of desirable skills for undergraduate students. Columbus High School for Girls, OH. (EDRS: no. ED307 893)

Benjamin, M. (1990). Freshman daily experience: Implications for policy, research and theory. (Student Development Monograph series v.4). Guelph, ON: University of Guelph.

Cannon, A. (1994). Faculty survey on library research instruction. $R Q, 33,541-542$.

Collins, B. L., Mellon, C.A. \& Young, S.B. (1987). The needs and feelings of beginning researchers. In Mellon C.A. (Ed.), Bibliographic instruction: The second generation ( $\mathrm{pp}$ 73-84). Littleton, CO: Libraries Unlimited.

Coupe, J. (1993). Undergraduate library skills: Two surveys at Johns Hopkins University. Research Strategies, 11 (4), 188-201.

Daragan, P. \& Stevens, G. (1996). Developing lifelong learners: An integrative and developmental approach to information literacy. Research Strategies, 14 (2), 68-81.

Debowski, S. (1996). Preparing our users for the future: The training needs of end users. In Reading the Future.( Proceedings of the Biennial Conference of the Australian Library and Information Association, Melbourne, Australia, 6-11 Oct.1996), 143-152.

Eisenberg, M. B. \& Brown, M.K. (1992). Current themes regarding library and information skills instruction: Research supporting and research lacking. School Library Media Quarterly, 20 (2), 103-110.

Eisenberg, M. B. \& Berkowitz, R. E. (1992). Information problem-solving: The Big Six skills approach. School Library Media Activities Monthly, 8 (5), 27-29, 37, 42.

Eisenberg, M. B. \& Johnson, D. (1996). Computer skills for information problem-solving: Learning and teaching technology in context. (EDRS: ERIC Digest no. EDO-IR-96-04)

Eisenberg, M. B. \& Spitzer, K.L. (1992). Skills and strategies for helping students become more effective information users. Catholic Library World, 63 (2), 115-120.

George, M. W. (1988). What do college librarians want freshmen to know? My wish list. Research Strategies, 6 (4), 189.

Goodin, M. E. (1991). The transferability of library research skills from high school to college. School Library Media Quarterly, 20 (1), 33-41. 
Jakobovits, L. \& Nahl-Jakobovits, D. (1987). Learning the library: A taxonomy of skills and errors. College and Research Libraries, 48 (3), 203-214.

Jesudason, M. (1993). Academic libraries and outreach services through precollege programs: A proactive collaboration. Reference Services Review, 21 (4), 29-36, 96.

Keefer, J. (1993). The hungry rats syndrome: Library anxiety, information literacy and the academic reference process. $R Q 32$ (3), 333-339.

Kester, D. D. (1994). Secondary school library and information skills: Are they transferred from high school to college? Reference Librarian 44, 9-17.

King, D. \& Baker, B. (1987). Human aspects of library technology. In C.C. Mellon (Ed.), Bibliographic Instruction: The second generation (pp 85-107). Littleton, CO: Libraries Unlimited.

Knudsen, C. \& Orpinela, J.(1992). Preparation High School or what students should know about libraries when they leave high school. Emergency Librarian, 19 (5), 12-14.

Krentz, R. F \& Gerlach, D.E. (1989). Library literacy of incoming freshmen. University of Wisconsin, Madison. (EDRS: no. ED346 866)

Kuhlthau, C. C. (1988). Developing a model of the library search process: Cognitive and affective aspects. $R Q 28(2), 232-242$.

Kuhlthau, C. C. (1991).The process approach to bibliographic instruction: An examination of the search process in preparation for writing the research paper. In L. Shirato (Ed.), Judging the validity of information source:Teaching critical analysis in bibliographic instruction. (Papers presented at the 18th National LOEX Library Instruction Conference, E. Michigan University, 11-12 May 1990).( pp 7-14). Ann Arbor, MI: Pierian Press.

Kuhlthau. C. C., Turock, B.J., George, M. \& Belvin, R.J. (1990). Validating a model of the search process: A comparison of academic, public and school library users. Library \& Information Science Research 12, 5-31.

Kunkel, L. R., Weaver, S.M. \& Cook, K.N. (1996). What do they know?: An assessment of undergraduate library skills. Journal of Academic Librarianship 22, (6), 430-434.

Leckie, G. (1996). Desperately seeking citations: Uncovering faculty assumptions about the undergraduate research process. Journal of Academic Librarianship 22 (2), 201-208.

Loomis, A. \& Fink, D. (1993). Instruction: Gateway to the virtual library. In L.M. Saunders (Ed.), Virtual library: Visions and realities (pp. 47-69). Westport, CT: Meckler.

Matheson, A \& Williams, R.(1985). Are your students ready? Library skills and post-secondary education. Alberta Learning Resources Journal 7 (3), 34-36.

McNeer, E. J. (1991 ). Learning theories and library instruction. Journal of Academic Librarianship 17 (5), 294-297.

Moore, P. (1995). Information problem solving: A wider view of library skills. Contemporary Educational Psychology 20, 1-31.

Nofsinger, M. N. (1989). Library use skills for college-bound high school students: A survey. Reference Librarian 24, 35-56.

Northumberland-Clarington Board of Education (1993). Library Automation Committee Report: Five year plan for computer-based technologies 1994-1999. Cobourg, ON: NorthumberlandClarington Board of Education.

Northumberland-Newcastle Board of Education (1983). Information skills:A continuum for Northumberland and Newcastle schools. Cobourg, ON: Northumberland-Clarington Board of Education.

Oberman, C. (1991). Avoiding the cereal syndrome, or critical thinking in the electronic environment. Library Trends 39 (3), 189-202.

Ontario Ministry of Education. (1982). Partners in action: The library resource centre in the school curriculum. Toronto: Ontario Ministry of Education.

Ontario Ministry of Education and Training. (1995). Information literacy and equitable access: A framework for change. Draft document. Toronto: Ontario Ministry of Education and Training.

Parenteau, A. (1994). Library user skills survey results: Draft report - whole sample. Unpublished. Alverno College, Milwaukee, WI.

University of Calgary, Information Library Group. (1996?). Undergraduate library use strategies: A qualitative analysis. [On-line] Available: http/www.ucalgary.ca/ jsday/its/ILG/survey.html. 
Valentine, B. (1993). Undergraduate research behavior: Using focus groups to generate theory. Journal of Academic Librarianship, 19 (5), 300-304.

[Waterloo County Library Liaison Committee]. [1994]. A guide for secondary school students and teachers to library resources in Waterloo County 1994-1995

Wesley, T. (1991). Teaching library research: Are we preparing students for effective information use? Emergency Librarian, 18 (3), 23-30.

Wollter, P. (1989). Development \&/or furthering library research skills for local junior and senior high school students. Sonoma State University: CA. (EDRS: no. ED 324 025)

York University Task Force on Faculties, Colleges and the First-Year Experience. (1996). February report to the Vice-President (Academic Affairs).[On-line] Available: http://www.yorku.ca/admin/ academic/tf-rpt5.htm. 